\title{
COMBATING HARASSMENT UNDER THE PROTECTION FROM HARASSMENT ACT 17 OF 2011 IN SOUTH AFRICA: DOES IT PUNISH VICTIMS AND PROTECT PERPETRATORS?
}

\author{
Bronwyn Le-Ann Batchelor \\ BComm (Law) LLB LLM \\ Head of Faculty: Law, Independent Institute of \\ Education
}

Shelton Tapiwa Mota Makore

LLB LLM LLD

TOT Lecturer, Nelson $R$ Mandela School of Law University of Fort Hare

\section{SUMMARY}

The Protection from Harassment Act 17 of 2011 (the Act) seeks to protect victims of harassment. Despite this legislative development, the effectiveness of the Act has not been widely explored. This article fills this cavity. It argues that the broadly drafted definition of harassment, together with other concomitant shortcomings in the Act, makes it prone to abuse by unscrupulous litigants, thereby militating against its regulatory efficiency goals. The article further maintains that the Act is constructed in an unbalanced manner as it protects the rights of complainants, but unintentionally is open to abuse, allowing, unfathomably, an alleged victim of harassment to become the harasser. The article analyses the regulatory aptness of the Act in an age marked by an exponential increase in cyber-related harassment and makes a case for enhancing the regulatory approach of the Act to offer an effective means of protecting victims of harassment in a rapidly evolving society.

\section{INTRODUCTION}

Harassment has become an endemic, perennial problem confronting contemporary societies with the media being awash with individuals subjected to it on the basis of social stratifications such as gender, race, 
ethnicity, nationality, religion, political affiliation and sexuality. ${ }^{1}$ Despite its prevalence, harassment sustains criminal liability because it possesses a direct affront to human dignity and privacy, among other fundamental human rights. $^{2}$ In an attempt to combat this crime, the South African legislature has enacted the Protection from Harassment $\mathrm{Act}^{3}$ (the Act) to protect individual fundamental human rights - inter alia, the right to equality, privacy, dignity and freedom, as well as security of person. ${ }^{4}$ To achieve this significant goal, the Act, aims specifically, among other things, to "afford victims of harassment an effective remedy against such behaviour". 5 Conceptually, legislation and policy drafted to inhibit the conduct of harassment by safeguarding fundamental rights, as the Act asserts it does, is necessary in a constitutional democracy. ${ }^{6}$ However, such legislation should be drafted to provide maximum protection to victims of harassment in a technological world, while minimising the frivolous abuse by unscrupulous litigants using an interpretation of the Act that creates unjust legal remedies. Equally, such maximum protection can only be achieved when the Act addresses not only traditional forms of harassment but also non-traditional forms of cyberrelated abuse that can occur through digital technology and other platforms. ${ }^{7}$

This article commences by unravelling the definitional scope and elements of harassment ${ }^{8}$ as provided for in the Act, taking into account the purpose of

1 Arndt "Street Harassment: The Need for Criminal Remedies" 201829 Hastings Women's Law Journal 81.

2 Chik "Harassment Through the Digital Medium A Cross-Jurisdictional Comparative Analysis on the Law on Cyberstalking" 20083 Journal of International Commercial Law and Technology 24; Volokh "One-To-One Speech vs One-to-Many Speech, Criminal Harassment Laws, and 'Cyberstalking'" 2013107 Northwestern University Law Review 760; Chemaly "Why We Need to Take Street Harassment Seriously" (28 September 2015) https://www.washingtonpost.com/news/parenting/wp/2015/09/28/why-we-need-to-takestreet-harassment-seriously/?utm term=.a745e8c8e594 (accessed 2020-03-25).

317 of 2011.

4 S 9 of the Constitution of the Republic of South Africa, 1996 provides: "(1) everyone is equal before the law and has the right to equal protection and benefit of the law. (2) Equality includes the full and equal enjoyment of all rights and freedoms. To promote the achievement of equality, legislative and other measures designed to protect or advance persons, or categories of persons, disadvantaged by unfair discrimination may be taken. (3) The state may not unfairly discriminate directly or indirectly against anyone on one or more grounds, including race, gender, sex, pregnancy, marital status, ethnic or social origin, colour, sexual orientation, age, disability, religion, conscience, belief, culture, language and birth. (4) No person may unfairly discriminate directly or indirectly against anyone on one or more grounds in terms of subsection (3). National legislation must be enacted to prevent or prohibit unfair discrimination. (5) Discrimination on one or more of the grounds listed in subsection (3) is unfair unless it is established that the discrimination is fair." The right to human dignity is provided in terms of section 10. It states that "everyone has inherent dignity and the right to have their dignity respected and protected." See The Constitution of South Africa, 1996. https://www.gov.za/documents/constitution-republic-south-africa-1996 (accessed 2020-03-26).

5 Preamble to the Act.

6 Landman and Ndou "The Protection from Harassment Act and its Implications for the Workplace" 201322 Contemporary Labour Law 82.

7 Smit "Cyberbullying in South African and American Schools: A Legal Comparative Study" 201535 South African Journal of Education 2.

8 In terms of $s$ 1(1) of the Act "harassment" occurs when "directly or indirectly engaging in conduct that the respondent knows or ought to know-

(a) causes harm or inspires the reasonable belief that harm may be caused to the complainant or a related person by unreasonably- 
the Act $^{9}$ and other relevant tools provided for juridical interpretation. By exploring the aforementioned, the objective is to determine whether the definition of harassment in the Act contributes to the achievement of the Act's purpose in the context of an evolving society. It is argued, in their current form, that the legal remedies in the Act allow for potential abuse. It is argued further that in securing and protecting the aforementioned rights, the potential for abuse has unintentionally been created, resulting in an undesirable situation whereby an alleged victim of harassment may become a "harasser" through the Act. The article then turns to examine whether the Act is adequate in a technology-based world. Finally, the article tenders a discussion on possible legislative reforms for the effective safeguarding of the rights of victims of harassment.

\section{THE ACT IN BRIEF: CONTEXTUAL AND HISTORICAL BACKGROUND}

Prior to 2011, the preventative measures in place to deal with harassment had many shortcomings and were not effectively beneficial to financially vulnerable complainants who had to endure, among other things, judicial bureaucracy before they could obtain a court order to protect their rights. ${ }^{10}$ The legal process was cumbersome, time-consuming and costly for complainants.

The Act seeks to ensure that complainants' rights are adequately protected. ${ }^{11}$ The Act consolidates the rights of the complainant by affording victims of harassment a legal remedy against such behaviour and introducing measures that enable the relevant organs of state to give full effect to the provisions of the Act. ${ }^{12}$

(i) following, watching, pursuing or accosting of the complainant or a related person, or loitering outside of or near the building or place where the complainant or a related person resides, works, carries on business, studies or happens to be;

(ii) engaging in verbal, electronic or any other communication aimed at the complainant or a related person, by any means, whether or not conversation ensues; or

(iii) sending, delivering or causing the delivery of letters, telegrams, packages, facsimiles, electronic mail or other objects to the complainant or a related person or leaving them where they will be found by, given to, or brought to the attention of, the complainant or a related person; or

(b) amounts to sexual harassment of the complainant or a related person.

9 The Preamble to the Act lays out the purpose of the Act panoramically: "Since the Bill of Rights in the Constitution of the Republic of South Africa, 1996, enshrines the rights of all people in the Republic of South Africa, including the right to equality, the right to privacy, the right to dignity, the right to freedom and security of the person, which incorporates the right to be free from all forms of violence from either public or private sources, and the rights of children to have their best interests considered to be of paramount importance; and in order to-

(a) afford victims of harassment an effective remedy against such behaviour; and

(b) introduce measures which seek to enable the relevant organs of state to give full effect to the provisions of this Act."

10 It is noteworthy that the Domestic Violence Act 116 of 1998 also defines domestic violence in s 1 (viii) to include the following: (e) intimidation; (f) harassment; and (g) stalking.

11 See Preamble to the Act.

12 See Preamble to the Act. 
Aside from the above, the adoption of the Act was necessitated by the growing and complex problems relating to defining harassment within the South African context and the need to introduce criminal and civil remedies to prevent or reduce violence in different forms of interpersonal relationship. ${ }^{13}$ Internationally, many countries have taken legislative action against harassment, recognising that such conduct is a public problem that merits attention. ${ }^{14}$ Harassment may have negative effects upon an individual such as causing behavioural, psychological and social problems. Specific risks to the victims of harassment may include loss of personal safety, loss of a job, sleeplessness, and a change in work or social habits. ${ }^{15}$ These effects are far-reaching with the potential to drain both criminal justice resources and the healthcare system. ${ }^{16}$

\section{THE DEFINITION AND CLASSIFICATION OF HARASSMENT}

Conceptually, harassment exists primarily in two major arenas - namely, either physical or cyber-related harassment. Classification is based on the nature of the perpetrator's conduct and the space in which the conduct occurs. ${ }^{17}$ This binary delineation is implicitly alluded to in the Act and is significant for the purpose of effectively combating all types of harassment. ${ }^{18}$ In terms of the Act, physical harassment occurs when a person watches, pursues or accosts a complainant or related person, or loiters outside of or near a building or place where the complainant or related person resides, works, carries on business, studies or happens to be. Physical harassment also includes engaging in verbal conduct aimed at the complainant or related person, by any means, whether or not conversation ensues. ${ }^{19}$ It includes the sending, delivering or causing delivery of letters, telegrams, packages, facsimiles, electronic mail or other objects to a complainant or related person or leaving them where they will be found by, given to or brought to the attention of, a complainant or related person. ${ }^{20}$ The Act also recognises that physical harassment can take another dimension when the conduct of the harasser amounts to sexual harassment. ${ }^{21}$ Such conduct may cause mental,

13 South African Law Reform Commission "Discussion Paper on Stalking" (undated) https://www.justice.gov.za/salrc/dpapers/dp108.pdf (accessed 2020-03-29).

14 Pende "Bullying and Sexual Harassment in the Legal Profession" (1 May 2019) https://www.unodc.org/res/ji/resdb/data/2019/us_too_bullying_and_sexual_harassment_in_t he_legal_profession_html/iba_us_too.pdf (accessed 2020-03-29).

15 Earle "An International Perspective on Sexual Harassment Law" 201712 Law and Inequality: A Journal of Theory and Practice 57-58.

16 Salter and Bryden "I Can See You: Harassment and Stalking on the Internet" 200918 Information and Communications Technology Law 102.

17 Sissing and Prinsloo "Contextualising the Phenomenon of Cyber Stalking and Protection from Harassment in South Africa" 201315 Acta Criminologica: African Journal of Criminology and Victimology 15.

$18 \mathrm{~S} 1(1)$ of the Act.

19 Pathe "Stalking by Law: Damaging Victims and Rewarding Offenders" 2004 Journal of Law and Medicine 103.

$20 \mathrm{~S} 1(1)$ of the Act.

21 A succinct case-law definition of sexual harassment was provided in $J v M L t d$ (1989) 10 ILJ 755 (IC) - that is, conduct that troubles another continually in the sexual sphere. This definition was further endorsed in Reddy v University of Natal (1998) 19 ILJ 49 (LAC). 
psychological, physical or economic harm. ${ }^{22}$ The Act clearly recognises the cyber aspect of harassment by indicating that harassment may occur through the medium of email or any other digital technology. Cassim ${ }^{23}$ observes that because cyber-related harassment occurs through digital platforms that connect many people it has become a common and more aggressive type of harassment with devastating effects on an individual's personhood. ${ }^{24}$

\section{THE ACT'S LEGAL APPROACH AND TEST OF HARASSMENT}

The overarching purpose of the Act is to allow for the issuing of protection orders against harassment in order to afford victims of harassment an effective remedy against such behaviour. ${ }^{25}$ The Act provides victims of harassment with a speedy and effective remedy in the form of a "protection order" or interdict whereas, previously, interdicts were only available through costly High Court litigation or from the domestic violence court in terms of the Domestic Violence Act, ${ }^{26}$ (DVA), which required the additional criteria of a domestic relationship to be applicable. The DVA together with the Act recognise that harassment may be experienced by the complainant in a number of ways. ${ }^{27}$

The court in Mnyandu $v$ Padayachi28 had to determine whether the conduct of the appellant (Mnyandu) constituted harassment in terms of section 1(1) of the Act. The applicant (Padayachi) alleged that his colleague had circulated an email that was defamatory, slanderous, libellous, dishonest, deceitful and malicious. ${ }^{29} \mathrm{He}$ contended that by circulating the email, the appellant impaired his dignity, defamed him, adversely affected his well-being and undermined his opportunity for promotion and financial benefit at his place of employment. ${ }^{30}$ The applicant could have used the common law to institute a claim for defamation or requested the employer to take disciplinary action against the appellant. Instead, the applicant elected to use the Act to found his claim. The applicant contended that the email circulated constituted harassment. ${ }^{31}$

The case was first heard in the magistrates' court, where it was held that the email sent by the appellant was sufficient to constitute harassment in terms of section $1(1)$ of the Act. ${ }^{32}$ The magistrates' court issued a final

22 Chicktay "Sexual Harassment and Employer Liability: A Critical Analysis of the South African Legal Position" 201054 Journal of African Law 283.

23 Cassim "Formulating Adequate Legislation to Address Cyber-Bullying: Has the Law Kept Pace with Advancing Technology?" 201826 South African Computer Journal 4.

24 Cassim 2018 South African Computer Journal 4 par 1.

25 See $\mathbf{s}$ of the Constitution, and Preamble to the Act.

26116 of 1998 .

27 Laas and Boezaart "The Legislative Framework Regarding Bullying in South African Schools" 201417 Potchefstroom Electronic Law Journal 373.

282017 (1) SA 151 (KZP).

29 Mnyandu v Padayachi supra par 6.5.

Mnyandu v Padayachi supra par 6.6.

Mnyandu $v$ Padayachi supra par 7.

Mnyandu v Padayachi supra par 26. 
protection order against the appellant. The magistrates' court held that the Act applies to the workplace. Consequently, employers and employees can invoke the provisions of the Act when subjected to harassment in the workplace. ${ }^{33}$ The appellant appealed to the High Court. The High Court maintained that the onus is on the applicant to prove on a balance of probabilities that the appellant knew, or ought to have known, that by sending the email, she was engaging in conduct that would cause harm to the applicant or inspire the reasonable belief that harm would be caused to him, be it mental, psychological, physical or economic, and that her conduct was unreasonable in the circumstances. ${ }^{34}$ The High Court noted that there is a scarcity of South African jurisprudence dealing with the Act and, in particular, with the interpretation of the word "harassment" as contained in the Act. The paucity and scarcity of jurisprudence on the Act militates against its application and interpretation. ${ }^{35}$

In order to compensate for the lack of jurisprudence, the High Court relied upon foreign jurisprudence sourced from the United Kingdom, Australia and Hong Kong. ${ }^{36}$ According to the Australian Queensland Criminal Code, there are certain elements required for conduct to constitute unlawful stalking (harassment). ${ }^{37}$ In particular, section 359B of the Queensland Criminal Code provides protection against intentionally directed conduct of a respondent whose objective is to harass an applicant provided it occurs on more than one occasion (protracted). Such conduct may consist in the act of sending one or more emails. It is the physical act of communication and not the contents of the communication that appears to be contemplated in subsections $(b)$ and $(c)$ of section 359B. ${ }^{38}$ Therefore, under the Queensland Criminal Code, the sending of one email (which is not a protracted act) may be considered to not constitute harassment as the conduct has not occurred on more than one occasion. ${ }^{39}$

\section{Mnyandu v Padayachi supra par 27. \\ Mnyandu v Padayachi supra par 6.2. \\ Mnyandu v Padayachi supra par 6.3.}

36 The indication that there is a lack of South African jurisprudence on the Act was also alluded to in par 1.34 of the South African Law Commission "Stalking Report of 2008" (undated) https://www.justice.gov.za/Salrc/reports/r_pr130_stalking.pdf (accessed 2020-0307).

37 Kift "Stalking in Queensland: From the Nineties to Y2K" 199911 Bond Law Review 105.

38 State of Queensland "Criminal Code Act 1899" (26 February 2020) https://www.legislation.qld.gov.au/view/pdf/inforce/current/act-1899-009 (accessed 2020-0305).

39 S 359B of the Queensland Criminal Code, titled "What is unlawful stalking", states: "Unlawful stalking is conduct-

(a) intentionally directed at a person (the stalked person); and

(b) engaged in on any 1 occasion if the conduct is protracted or on more than 1 occasion; and

(c) consisting of 1 or more acts of the following, or a similar, type-

(i) following, loitering near, watching or approaching a person;

(ii) contacting a person in any way, including, for example, by telephone, mail, fax, email or through the use of any technology;

(iii) loitering near, watching, approaching or entering a place where a person lives, works or visits;

(iv) leaving offensive material where it will be found by, given to or brought to the attention of, a person; 
Under the auspices of the same Australian Queensland Criminal Code, for harassment to occur, the contents of the communication must be such that it causes detriment to the stalked person. ${ }^{40}$ Section 359A of the Queensland Criminal Code provides definitions for key words and phrases. It defines detriment in terms of the consequences of the stalking behaviour, which include: (a) apprehension of fear or violence to, or against the property of, the stalked person or another person; and (b) serious mental, psychological or emotional harm. ${ }^{41}$ The victim must therefore establish that the

(v) giving offensive material to a person, directly or indirectly;

(vi) an intimidating, harassing or threatening act against a person, whether or not involving violence or a threat of violence;

(vii) an act of violence, or a threat of violence, against, or against property of, anyone, including the defendant; and

(d) that-

(i) would cause the stalked person apprehension or fear, reasonably arising in all the circumstances, of violence to, or against property of, the stalked person or another person; or

(ii) causes detriment, reasonably arising in all the circumstances, to the stalked person or another person."

40 S 359A of the Queensland Criminal Code provides "definitions for ch 33A": "In this chaptercircumstances means the following circumstances-

(a) the alleged stalker's circumstances;

(b) the circumstances of the stalked person known, foreseen or reasonably foreseeable by the alleged stalker;

(c) the circumstances surrounding the unlawful stalking;

(d) any other relevant circumstances.

property, of a person, means-

(a) property in which the person has an interest, whether or not the defendant also has an interest in the property; or [Note under the Acts Interpretation Act 1954, schedule 1 interest, in relation to land or other property, means-

(a) a legal or equitable estate in the land or other property; or

(b) a right, power or privilege over, or in relation to, the land or other property.]

(b) property that is otherwise-

(i) used and enjoyed by the person; or

(ii) available for the person's use or enjoyment; or

(iii) in the person's care or custody; or

(iv) at the premises at which the person is residing

stalked person see s 359B.

unlawful stalking see s 359B.

violence-

(a) does not include any force or impact within the limits of what is acceptable as incidental to social interaction or to life in the community; and

(b) against a person includes an act depriving a person of liberty; and

(c) against property includes an act of damaging, destroying, removing, using or interfering with the property.

41 S 359A of the Queensland Criminal Code provides "definitions for ch 33A": "In this chapter-: detriment includes the following-

(a) apprehension or fear of violence to, or against property of, the stalked person or another person;

(b) serious mental, psychological or emotional harm;

(c) prevention or hindrance from doing an act a person is lawfully entitled to do;

(d) compulsion to do an act a person is lawfully entitled to abstain from doing.

Examples of paragraph (c) - a person no longer walks outside the person's place ofresidence or employment. A person significantly changes the route or form of transport the person would ordinarily use to travel to work or other places.

Example of paragraph (d) - a person sells a property the person would not otherwise sell. 
communication caused him fear of physical violence to person or property, or serious mental, psychological or emotional harm. Finally, an objective test is employed to determine whether or not the conduct indeed caused harm. In other words, harm must reasonably arise from the relevant circumstances. ${ }^{42}$

Similarly, the South Australian Criminal Law Consolidation (Stalking) Amendment Act 7 of 1994 prescribes that the conduct complained of should occur on at least two separate occasions and reasonably arouse the victim's apprehension or fear. ${ }^{43}$ In the same vein, the Law Reform Commission of Hong Kong in its groundbreaking Report on Stalking opines that, for a finding of stalking to be made, a stalker must pursue a course of conduct that amounts to harassment of another; the harassment should be serious enough to cause that person alarm or distress; and a reasonable person would have to think that the course of conduct amounted to harassment of the other. ${ }^{44}$ This submission resonates with section 1(2) of the South African Act, which provides that the person whose course of conduct is in question ought to know that it amounts to harassment of another if a reasonable person in possession of the same information would understand (or foresee) that the course of conduct amounted to harassment of the other. ${ }^{45}$

In Dowson v Chief Constable of Northumbria Police, ${ }^{46}$ the court provided a summary of what must be proved in law for a claim of harassment to succeed: (a) there must be conduct which occurs on at least two occasions; (b) which is targeted at the Claimant; (c) which is calculated in an objective sense to cause alarm or distress; (d) which is objectively judged to be oppressive and unacceptable; (e) what is oppressive and unacceptable may depend on the social or working context in which the conduct occurs; (f) a line is to be drawn between conduct that is unattractive and unreasonable, and conduct that has been described in various ways as tormenting the victim. ${ }^{47}$

Emphatically, the legal test as to whether a person is guilty of harassment is objective in nature. ${ }^{48}$ This means it entails an assessment of the conduct by a reasonable person, a total departure from the elements of many criminal offences, which require a degree of intent before an offence is committed. ${ }^{49}$ Such a divergence is justified as many harassers claim that

42 Purcell, Pathé and Mullen "Stalking: Defining and Prosecuting a New Category of Offending" 200430 International Journal of Law and Psychiatry 167.

43 This test was clearly laid out in $R v$ Smith (2013) 2 All ER 804 par 25 Court of Appeal, Australia; Thomas $v$ News Group Newspapers Ltd (2002) EMLR 78 Supreme Court of Appeal, Australia; and Rv Curtis (2010) 3 All ER 849 par 29 Court of Appeal, Australia.

44 The Law Reform Commission of Hong Kong Report "Stalking" (undated) http://www.worldlii.org/hk/other/hklrc/reports/2000/3/stalk-Chapter-6.html (accessed 202003-27).

$45 \mathrm{~S} 1(1)$ of the Act.

46 (2010) All ER (D) 191 par 142 (2006) 4 All ER 395 England and Wales High Court, England. This case centered on whether allegations made against the Chief Constable of police by his colleagues amounted to harassment under the Protection from Harassment Act 1997.

47 Dowson v Chief Constable of Northumbria Police (2010) All ER (D) 192 par 143.

48 Middlemiss "Let the Stalker Beware? Analysis of the Law of Stalking in Scotland" 201478 Journal of Criminal Law 407.

49 Middlemiss 2014 Journal of Criminal Law 407 par 1. 
they have no intention of harassing their victims. In another UK case, Majrowski $v$ Guy's and St Thomas's NHS Trust, ${ }^{50}$ the court held that the purpose of the Protection from Harassment Act ${ }^{51}$ is to protect victims of harassment, whatever form the harassment, wherever it occurs and whatever its motivation. ${ }^{52}$ The court reasoned that the Act seeks to provide protection against stalkers, racial abusers, disruptive neighbours, bullying at work and so forth. Similarly, elements required to constitute harassment in terms of the UK anti-harassment laws dictate that the prohibited conduct must occur more than once and a reasonable person in the position of the offender must foresee and understand that the course of conduct amounted to harassment. ${ }^{53}$

(2006) 4 All ER 395 House of Lords of the United Kingdom.

51 Protection from Harassment Act of 1997.

52 Notably in United Kingdom, the Protection from Harassment Act 1997 provides:

"S 1: Prohibition of harassment

(1) A person must not pursue a course of conduct-

(a) which amounts to harassment of another, and

(b) which he knows or ought to know amounts to harassment of the other.

(2) For the purposes of this section, the person whose course of conduct is in question ought to know that it amounts to harassment of another if a reasonable person in possession of the same information would think the course of conduct amounted to harassment of the other.

(3) Ss (1) does not apply to a course of conduct if the person who pursued it shows-

(a) that it was pursued for the purpose of preventing or detecting crime,

(b) that it was pursued under any enactment or rule of law or to comply with any condition or requirement imposed by any person under any enactment, or

(c) that in the particular circumstances the pursuit of the course of conduct was reasonable.

S 2: Offence of harassment:

(1) A person who pursues a course of conduct in breach of section 1 is guilty of an offence.

$\ldots$

S 4: Putting people in fear of violence

(1) A person whose course of conduct causes another to fear, on at least two occasions, that violence will be used against him is guilty of an offence if he knows or ought to know that his course of conduct will cause the other so to fear on each of those occasions.

(2) For the purposes of this section, the person whose course of conduct is in question ought to know that it will cause another to fear that violence will be used against him on any occasion if a reasonable person in possession of the same information would think the course of conduct would cause the other so to fear on that occasion.

S 7: Interpretation of this group of sections

(1) This section applies for the interpretation of sections 1 to 5 .

(2) References to harassing a person include alarming the person or causing the person distress."

$53 \quad R v$ Smith supra par 24. The court stated that "[i]n construing section 1 of the 1997 Act it is right to have regard to the type of mischief at which it was aimed. It is also right to have regard to what the ordinary person would understand by harassment. It does not follow that because references to harassing a person include alarming a person or causing a person distress (s 7(2)), any course of conduct which causes alarm or distress amounts to harassment.... So to reason would be illogical and would produce perverse results.... the definition of the word "harass" in the Concise Oxford Dictionary ... [means] to "torment by subjecting to constant interference or intimidation'.... Essentially, it involves persistent conduct of a seriously oppressive nature, either physically or mentally, targeted at an individual or resulting in fear or distress." In $R v$ Curtis supra, the court held that the impugned conduct must be unacceptable to a degree which would sustain criminal liability 
Based on the aforementioned jurisprudence, the High Court in Myandu $v$ Padayachi overturned the decision of the magistrates' court and ruled in favour of the appellant. ${ }^{54}$ The High Court found that although the Act was applicable in the workplace, the appellant did not harass the applicant. ${ }^{55}$ The High Court held that although the conduct of the appellant in sending the email may have been unreasonable, because she allowed her emotions to cloud her perception, it was not objectively oppressive nor had the gravity to constitute harassment in terms of the Act. ${ }^{56}$ The High Court held that while the applicant alleged that his prospects of promotion, his dignity and reputation within his company and community were compromised as a consequence of the email, there was no evidence to this effect. ${ }^{57}$ Therefore, the High Court was unable to find that the facts of this matter sustained a finding that the conduct of the appellant constituted harassment as contemplated by the Act, and the appeal succeeded. ${ }^{58}$

It is apparent from the aforementioned cases that the offence of harassment is not merely constituted by a course of conduct that is oppressive and unreasonable; the consequences or effect of the conduct ought not merely to cause a degree of alarm, but must cause serious fear, alarm and distress. The legal test is always an objective one: the conduct must be calculated in an objective sense to cause alarm or distress, and be objectively judged as oppressive and unacceptable. ${ }^{59}$ As Chik ${ }^{60}$ opines, an objective test is subjective in nature, applied to particular facts and circumstances. In other words, a person ought to know (or foresee) that his course of conduct amounts to harassment of another if a reasonable person in possession of the same information would know (or foresee) that the course of conduct would result in the prohibited types of effect on the other.

and must also be oppressive. The court agreed with the following analysis in Thomas $v$ News Group Newspapers Ltd supra par 29-30: "Section 7 of the 1997 Act does not purport to provide a comprehensive definition of harassment. There are many actions that foreseeably alarm or cause a person distress that could not possibly be described as harassment. It seems ... that section 7 is dealing with that element of the offence which is constituted by the effect of the conduct rather than with the types of conduct that produce that effect. The Act does not attempt to define the type of conduct that is capable of constituting harassment. 'Harassment' is, however, a word which has a meaning which is generally understood. It describes conduct targeted at an individual which is calculated to produce the consequences described in section 7 and which is oppressive and unreasonable. The practice of stalking is a prime example of such conduct." See SATAWU obo Dlamini / Transnet Freight Rail, a Division of Transnet Ltd [2009] JOL 24429 (TOKISO). Mnyandu v Padayachi supra par 73.

55 In SATAWU obo Dlamini / Transnet Freight Rail, a Division of Transnet Ltd supra, the arbitrator held that "harassment is a form of unfair discrimination, and that although harassment is generally understood to denote repeated conduct a single extremely serious slur on the grounds of race could constitute harassment. He held further that although the test for establishing discrimination is objective, the Constitution requires that the primary focus be on the effect on the complainant of the action complained of, and that the proper test for assessing whether the conduct constituted harassment is by reference to the reasonable victim".

56 Mnyandu v Padayachi supra par 71.

57 Mnyandu v Padayachi supra par 70.

58 Mnyandu v Padayachi supra par 73.

59 The objective test is instrumental because it ensures that irrational stalkers or stalkers who are mentally ill fall within the ambit of regulation and that their conduct is subject to legal "remedies".

60 Chik 2008 Journal of International Commercial Law and Technology 33. 
The effect on the victim is objectively determined, and actual proof of resulting harm is immaterial. ${ }^{61}$

In terms of the Act and South African case law, one event is sufficient to constitute harassment, provided harm can be proven by the complainant. A course or pattern of events does not have to be proved in order for harassment to have occurred.

\section{FACTORS CONSIDERED BY A COURT WHEN GRANTING A PROTECTION ORDER}

In terms of the Act, a court, in deciding whether the conduct of a respondent is unreasonable, must in addition to any other factor take into account whether the conduct, in the circumstances in question, was engaged in for the purposes of detecting or preventing an offence; to reveal a threat to public safety or the environment; to reveal that an undue advantage is being or was given to a person in a competitive bidding process; or to comply with a legal duty. ${ }^{62}$ Anyone, including a child, who is subjected to unwanted attention, may apply for a protection order at the magistrates' court nearest to where either the complainant or the harasser resides or is employed, or to where the harassment is occurring. ${ }^{63}$

It is not necessary for the complainant to engage the assistance of an attorney in order to launch this application. The complainant simply completes the relevant application form, obtainable at the court or online, and provides the details of the harassment and the reasons the protection sought is necessary. ${ }^{64}$ The court must consider such an application after submission as soon as reasonably possible. ${ }^{65}$ If the court is satisfied that there is prima facie evidence that (a) the respondent (harasser) is engaging or has engaged in harassment; (b) harm is being or may be suffered by the complainant or a related person as a result of that conduct if a protection order is not issued immediately; and (c) the protection to be accorded by the interim protection order is likely not to be achieved if prior notice of the application is given to the respondent, the court must, notwithstanding the fact that the respondent has not been provided with notice of the proceedings, issue an interim protection order against the respondent. ${ }^{66}$

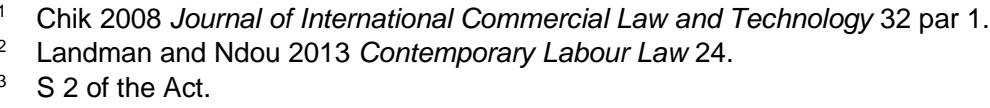

64 Soekoe "Protection From Harassment Act Simplified" (11 April http://www.wlce.co.za/index.php/2013-04-30-11-57-18/2013-04-30-12-22-01/240-theprotection-from-harassment-act-simplified (accessed 2014-04-16).

65 You can obtain a protection order against any person who perpetrates harassment even if the perpetrator is a child who is old enough to appreciate the consequences of his or her actions and who knew or ought to have known that the conduct was harmful. You do not have to be in any form of a domestic relationship with the perpetrator in order to apply for a protection order. Children over the age of 14 are legally regarded as being mature enough to understand the difference between right and wrong and can be criminally charged if they commit a criminal act such as breaching a protection order. A court may be reluctant to grant an order against a child under the age of 14 as a child under the age of 14 might not necessarily understand the difference between right and wrong.

$66 \mathrm{~S} 3$ of the Act. 
After the issuing of an interim order, there will be an opportunity at a later stage for the respondent to defend him- or herself before a final order is granted. Such an order is granted on the balance of probabilities that the respondent has engaged or is engaging in harassment. Such an order, including an interim protection order, may prohibit the respondent from certain conduct $^{67}$ and may impose any additional conditions on the respondent deemed reasonably necessary to protect and provide for the safety or well-being of the complainant. ${ }^{68}$ Whenever a court issues a protection order, including an interim protection order, the court must make an order authorising the issuing of a warrant for the arrest of the respondent and suspending the execution of that warrant subject to compliance with any prohibition, condition, obligation or order imposed. This means that the harasser may be "automatically" arrested without further proceedings for failure to adhere to the requirements of such an order and may face imprisonment for up to five years. ${ }^{69}$

If an interim order is not sought, or if the court decides not to issue such an order, the court must direct that the application for a court order be served on the respondent and that the respondent be given notice of the fact that he or she must show cause, on a date stated in the notice, as to why the order should not be granted..$^{70}$ All the defences the respondent may raise as justification for his or her conduct require the respondent to have a specific purpose. Some guidance on what constitutes purpose may be derived from the UK S case in Hayes (FC) $v$ Willoughby. ${ }^{71}$ The defence of Willoughby, the alleged harasser, was that he was engaged in the prevention or detection of crime; a recognised defence in terms of section 1(3) of the equivalent Act in the United Kingdom. The trial judge found that Willoughby's campaign of correspondence with the various public authorities concerning a Mr Hayes amounted to harassment. However, the trial judge found that Willoughby's conduct was gratuitous, for apart from some modest financial claims against Mr Hayes, almost all of which were resolved at an early stage of his campaign, he had no personal interest in establishing his allegations against Mr Hayes. ${ }^{72}$ The majority of the UK Supreme Court noted that their decision on the standard by which a person's purpose is to be assessed was divided between an objective ${ }^{73}$ and a subjective test. ${ }^{74}$ The majority of the court declined to accept either a stark objective or an equally stark subjective test,

67 An interim protection order, may prohibit the respondent from:

(a) engaging in or attempting to engage in harassment;

(b) enlisting the help of another person to engage in harassment; or

(c) committing any other act as specified in the protection order.

68 An "additional condition" may well be an order that the harasser may not be within a specific radius of the complainant. See $\mathrm{s} 9$ and 10 of the Act.

$69 \mathrm{~S} 11$ of the Act.

70 Landman and Ndou 201322 Contemporary Labour Law 81-82.

(2013) UKSC 17 UK Supreme Court.

Hayes (FC) $v$ Wiloughby supra par 3.

73 KD v Chief Constable of Hampshire (2005) EWHC 2550 (QB) 144 England and Wales High Court, United Kingdom. Also mentioned in Hayes (FC) v Wiloughby (2013) UKSC 17 par 10.

74 EDO MBM Technology Ltd v Axworthy (2005) EWHC 2490 (QB) par 28-29 Queen's Bench, United Kingdom. Also mentioned in Hayes (FC) v Wiloughby (2013) UKSC 17 par 1, 10 and 26. 
but opted for a test that is well known in our constitutional dispensation, being the test of rationality. ${ }^{75}$

Therefore, essentially the purpose of the Act is to enforce and protect the complainant's rights enshrined in the Constitution, specifically the right to freedom and security of the person (section 12), ${ }^{76}$ the right to dignity (section 10), and the right to equality (section 9). However, we find that the aforementioned rights are in competition with those of the respondent namely, freedom of movement and residence (section 3), privacy (section 14), ${ }^{77}$ and freedom of expression in terms of section 16. ${ }^{78}$. Hence, the complainant's alleged infringed rights will need to be balanced with those of the respondent by using the limitation of rights clause in the Constitution in order to deploy a remedy that does justice between the parties. ${ }^{79}$

\section{DOES THE DEFINITION OF HARASSMENT CONTRIBUTE TO THE ACT ACHIEVING ITS PURPOSE?}

Before the Act, protection orders were only available to people experiencing physical, sexual, emotional, verbal, psychological, economic and other forms of abuse from a person with whom they had a domestic relationship in terms of the DVA. ${ }^{80}$ This meant that applicants could only obtain a protection order

75 Hayes (FC) v Wiloughby (2013) UKSC 17 par 14.

76 In terms of $s 12$ of the Constitution:, "(1) Everyone has the right to freedom and security of the person, which includes the right (a) not to be deprived of freedom arbitrarily or without just cause; (b) not to be detained without trial; (c) to be free from all forms of violence from either public or private sources; (d) not to be tortured in any way; and (e) not to be treated or punished in a cruel, inhuman or degrading way. (2) Everyone has the right to bodily and psychological integrity, which includes the right- (a) to make decisions concerning reproduction; (b) to security in and control over their body; and (c) not to be subjected to medical or scientific experiments without their informed consent."

77 S 14 of the Constitution states: "Everyone has the right to privacy, which includes the right not to have- (a) their person or home searched; (b) their property searched; (c) their possessions seized; or (d) the privacy of their communications infringed."

78 According to the Constitution, freedom of expression is guaranteed in terms of $s$ 16(1), which provides that "everyone has the right to freedom of expression, which includes- (a) freedom of the press and other media; (b) freedom to receive or impart information or ideas; (c) freedom of artistic creativity; and (d) academic freedom and freedom of scientific research. (2) The right in ss (1) does not extend to (a) propaganda for war; (b) incitement of imminent violence; or (c) advocacy of hatred that is based on race, ethnicity, gender or religion, and that constitutes incitement to cause harm."

79 S 36 of the South African Constitution provides the limitation clause. It maintains: "(1) The rights in the Bill of Rights may be limited only in terms of law of general application to the extent that the limitation is reasonable and justifiable in an open and democratic society based on human dignity, equality and freedom, taking into account all relevant factors, including - (a) the nature of the right; (b) the importance of the purpose of the limitation; (c) the nature and extent of the limitation; (d) the relation between the limitation and its purpose; and (e) less restrictive means to achieve the purpose. (2) Except as provided in subsection (1) or in any other provision of the Constitution, no law may limit any right entrenched in the Bill of Rights."

80 The procedure to follow in obtaining a domestic protection order in terms of the Domestic Violence Act 116 of 1998 is as follows. The application can be made at any magistrates' court having jurisdiction over the area:

(a) where the complainant resides (temporarily or permanently) or works;

(b) where the respondent resides or works; or 
against someone to whom they were married or engaged, or with whom they were in a romantic, intimate or sexual relationship; their parent, child or family member, or someone with whom they were living. By contrast, a person wishing to obtain a protection order under the Protection from Harassment Act (the Act) is not required to prove the existence of a domestic relationship, which was often a hurdle to obtaining protection, such as in instances of abuse between an educator and a learner.

The Act does not prohibit a person from applying for a protection order under the DVA if he or she falls into the category of being in a domestic relationship. Hence, in certain instances, a complainant may have recourse under both the Act and the DVA. The Act only requires the complainant to make a prima facie case that he or she has been harassed by the respondent. The court will then grant an interim protection order and an arrest warrant will be issued but will be suspended. It is therefore a relatively simple remedy to obtain. ${ }^{81}$ If the complainant does not have, or is not in the process of applying for a protection order against harassment or stalking as provided for in the DVA, the court may not refuse to issue a protection order, or to impose any condition or make any order, which it is competent to impose or make in terms of the Act merely on the grounds that other legal remedies are available to the complainant. ${ }^{82}$

(c) where the act or acts of domestic violence took place.

The complainant is required to complete a prescribed form setting out the nature of the domestic violence against which he or she requires protection as well as the nature of the domestic relationship between him or herself and the respondent. Supporting documentation such as witness reports, medical evidence and statements from persons having knowledge of the domestic violence should, where possible, be attached to the application. Given the nature of abuse and the fact that it generally takes place behind closed doors in the absence of outsider presence, the absence of supporting documentation will not disqualify the complainant in obtaining the necessary protection order. The application for the protection order can be made on behalf of the complainant by a third party including among others a social worker, counsellor, health service provider, or a relative. Where the application is made by a third party, the complainant's written consent must be handed to the court. No consent is required where the complainant is a minor, mentally disabled, or unable to provide the requisite consent. A minor may approach the court for an order without the consent of his or her parent or guardian. Once the application has been completed, the clerk of the court will submit the application papers to the relevant magistrate who will, in the event that he or she is satisfied that the respondent is committing or has committed the acts of domestic violence and that the complainant will suffer hardship if an order is not immediately granted, grant an interim protection order against the respondent. Where the court is not satisfied, for whatever reason, the court will notify the complainant and the respondent to attend court on an allotted date for further decision. An interim protection order is of a temporary nature only and a date will be set by the magistrate and recorded on the interim protection order for return where the respondent will be provided an opportunity to show the court why a final order should not be made in the complainant's favour. The clerk of the court will arrange for a copy of the application papers together with a copy of the interim protection order to be served by the sheriff, or a member of the South African Police Services on the respondent. Service by the police is normally only required where there is a likelihood of resistance to service. On the return date, the court will consider the respondent's evidence. Where the court is satisfied on a balance of probability that the respondent has committed or is committing an act of domestic violence, it will issue a final order against the respondent. This order will remain in force until such time as it is set aside by another court.

81 Landman and Ndou 201322 Contemporary Labour Law 90.

82 Landman and Ndou 201322 Contemporary Labour Law 83-84. 
If the person who is engaged in conduct that constitutes harassment is doing so electronically 83 over the Internet or by email (otherwise known as ecomm) and as a result they retain their anonymity, the Act allows the court to request details of the person from the electronic communications service provider or may order an investigation by the police to obtain the details of the alleged harasser. ${ }^{84}$ The Act defines an "electronic communication service provider" with reference to the Regulation of Interception of Communication and Provision of Communication-Related Information Act ${ }^{85}$ (RICPCl), where it is defined as any:

"(a) person who provides an electronic communication service under and in accordance with an electronic communication service licence issued to such person under Chapter 3 of the Electronic Communications Act, ${ }^{86}$ and includes any person who provides - (i) a local access communication service, public pay-telephone service, value-added network service or private electronic communication network as defined in the Electronic Communications Act; or

(ii) any other electronic communication service licensed or deemed to be licensed or exempted from being licensed as such in terms of the Electronic Communications Act; and (b) Internet service provider." ${ }^{87}$

If the court is satisfied that a protection order should be issued where the identity of the electronic harasser is unknown, the court may issue a direction ordering a service provider to furnish the court with the harasser's information. ${ }^{88}$ The interception of such information provided must comply with section 6 of the RICPCI.89

As the interim order has to be served after being granted, mobile operators and Internet service providers (ISPs) can be asked to locate relevant parties. Electronic service providers can be forced to hand over the name, surname, identity number and address of the person to whom the IP address, email or cellular phone number belongs, and ISPs that fail to hand over information can be fined R10 000, while their staff could be imprisoned for six months. ${ }^{90}$

The Act assumes that in all cases ISPs would be able to provide details of the identity of an individual online. However, there are cases where South African ISPs would be unable to assist if the online activity took place outside of South Africa. In those instances, law enforcement officials would be required to make inquiries with international companies, such as Google or Facebook. There are so many tools of obfuscation available that a determined perpetrator will be able to circumvent the law unless the service providers, as well as law enforcers themselves, are as well-versed in these tools as the perpetrators.

83 Harassment via phone, SMS, email and social media is so widespread; it has developed into a layer of emotional abuse that simmers just below the surface of our nation's psyche.

84 Bick "SA's New Harassment Act Explained" (22 April 2013) http://www.women24.com/CareersAndMoney/Legal/SAs-new-Harassment-Act-explained20130422T (accessed 2014-06-16).

8570 of 2002.

8636 of 2005.

87 S 1 of the Act. Landman and Ndou 201322 Contemporary Labour Law 82-83.

88 Landman and Ndou 201322 Contemporary Labour Law 83.

89 Ibid.

$90 \mathrm{~S} 18(4)(b)$ of the Act. 
The service provider must provide the information or respond that it does not have the required information within five ordinary court days. However, before providing the information, the service provider must, at least 48 hours before it does so, inform the respondent of the information that is to be provided to the court. Failure to provide the information to the court as required is a criminal offence in terms of the Act. ${ }^{91}$

The Act provides a victim with remedies that were previously not at their disposal owing either to the cost required or the requirements to be met. Thus, the Act has produced an environment conducive to easily obtaining a protection order and warrant of arrest, albeit suspended, so as to protect the fundamental rights of the complainant and thus achieve the purpose of the Act. However, the ease of obtaining a protection order in terms of the Act has indirectly and possibly inadvertently simultaneously produced an environment wherein an alleged respondent's rights may far too easily be infringed, curtailed and/or limited, sometimes without even adherence to the audi alteram partem principle in circumstances where an ex parte interim protection order is granted.

\section{POTENTIAL ABUSE OF AVAILABLE REMEDIES}

The Act, although a welcome piece of legislation, poses several practical problems that include, but are not limited to, the possible abuse of the Act by unscrupulous litigants, and the circumvention of the Act by cyberbullies. Just as the DVA is susceptible to abuse in divorce cases, the Act is also open to abuse. The Act differs from the DVA in at least two ways: first, the Act does not require a domestic relationship for it to be used; such a criterion often formed a deterrent to those litigants who merely wished to use the DVA for self-seeking or vengeful purposes. Secondly, the definition of harassment indicates that there is no need for a pattern of behaviour to be shown or proved to access the remedies in the Act. Essentially, behaviour in the form of a single text message or comment may comply with the definition of harassment in the Act. ${ }^{92}$

Furthermore, section 2(4) of the Act ${ }^{93}$ goes beyond sections 14 and 15 of the Children's Act ${ }^{94}$ by reducing the common-law limitations on a child's capacity to litigate and to have access to a court of law. ${ }^{95}$ Therefore, it becomes possible for school children to become litigants; schoolyard disputes are now easily brought to the arena of the harassment court. It is envisaged that this will occur in that the source of harassment by way of electronic media or online communication is most commonly used by the younger generation. The Act and its remedies become that much more susceptible to abuse as it is now available to minors without the assistance

\footnotetext{
S 18(4)(a) of the Act.

Refer to $s$ of the Act.

93 See s 2(4) of the Act, which states: "Notwithstanding the provisions of any other law, any child, or person on behalf of a child, may apply to the court for a protection order without the assistance of a parent, guardian or any other person."

9438 of 2005.

95 Chik 2008 Journal of International Commercial Law and Technology 26.
} 
or consent of their parents who would normally provide reasoning and judgment before approaching the court for relief.

As easy as it is to perpetrate abuse under the cloak of anonymity through cyberbullying, it is likewise easy to fabricate abuse in order to incite police action against a supposed perpetrator. In a worst-case scenario, the application of the Act could result in the abuse of the right to privacy, which it is designed to protect.

Section 18 of the Act provides for certain criminal offences including the contravention of any prohibition, condition, obligation or order imposed by the court by means of a protection order, including an interim order; and the making of a false statement in a material respect in an affidavit stating that the respondent has contravened the prohibition, condition, obligation or order imposed by the court by means of a protection order, including an interim order. ${ }^{96}$ Therefore, the Act does provide recourse for a person who is wrongly arrested on a warrant of arrest issued based on a protection order. However, there does not seem to be any offence created or remedy provided for a respondent who finds him- or herself continually at court on fabricated allegations.

It appears that the Act, while providing ease of use for a complainant has failed to consider the possibility of an unscrupulous complainant using the Act for vengeful self-seeking reasons. This may result in a complainant continually calling a respondent to court to oppose applications for protection orders, thereby causing the alleged harasser to be in fact harassed. The Act's remedy is for the respondent to prove that the complainant has made a false statement in an affidavit referred to in section 11(4)(a) of the Act; the complainant would then be guilty of an offence and liable on conviction to a fine or imprisonment for a period not exceeding five years. ${ }^{97}$ The Act further provides that the court may only make an order as to costs against any party if it is satisfied that the party in question has acted frivolously, vexatiously or unreasonably. The aforementioned remedies may be irrelevant to a respondent who seeks to prevent a complainant from continually harassing him or her by launching vexatious, frivolous or unreasonable applications to which he or she is compelled to answer in an endeavour to prevent an order being granted to his or her detriment.

It appears that such a respondent's remedy lies in section $2(1)(b)$ of the Vexatious Proceedings Act, ${ }^{98}$ which states as follows:

"If, on an application made by any person against whom legal proceedings have been instituted by any other person or who has reason to believe that the institution of legal proceedings against him is contemplated by any other person, the court is satisfied that the said person has persistently and without any reasonable ground instituted legal proceedings [own emphasis added] in any court or in any inferior court, whether against the same person or against different persons, the court may, after hearing that person or giving him an opportunity of being heard, order that no legal proceedings shall be instituted

96 Landman and Ndou 201322 Contemporary Labour Law 84.

$97 \mathrm{~S} 18$ of the Act. Any proceedings under subsection (1) shall be deemed to be civil proceedings within the meaning of $s 3(c)$ of the Appellate Division Further Jurisdiction Act 1 of 1911.

983 of 1956. 
by him against any person in any court or any inferior court without the leave of the court, or any judge thereof, or that inferior court, as the case may be, and such leave shall not be granted unless the court or judge or the inferior court, as the case may be, is satisfied that the proceedings are not an abuse of the process of the court and that there is prima facie ground for the proceedings."

An order in terms of section 2(1)(a) or (b) of the Vexatious Proceedings Act may be issued for an indefinite period or for such period as the court may determine, and the court may at any time, on good cause shown, rescind or vary any order issued. ${ }^{99}$ Any person against whom an order has been made under section 2(1) who institutes any legal proceedings against any person in any court or any inferior court without the leave of that court or a judge thereof or that inferior court (in other words without first obtaining the necessary probalis causa certificate), shall be guilty of contempt of court and be liable upon conviction to a fine not exceeding one hundred pounds or to imprisonment for a period not exceeding six months. ${ }^{100}$

The remedy available for "harassed" respondents in terms of the Vexatious Proceedings Act is a remedy to be implemented in the High Court, which once again exposes the respondent to the costs occasioned by such remedy whereas the complainant has the ease and advantage of using the tools available at his or her disposal in the magistrates' court. Unfortunately, the magistrates' court has no inherent jurisdiction at common law to prevent the future institution of vexatious proceedings and hence, besides the remedies provided in the Act as enunciated above, the court has no other power to prevent the abuse of the Act. A respondent who finds him or herself in such a position will be compelled, if aware, to use the Vexatious Proceedings Act as this Act's purpose is to protect individuals against the institution of future vexatious proceedings.

In terms of our common law, a respondent who finds him or herself the victim of vexatious harassment proceedings may apply to court for the complainant's claim to be struck out on the basis that the claim is vexatious, frivolous and improper; ${ }^{101}$ in terms of Reichel v Magrath, ${ }^{102}$ every court has inherent rights to prevent an abuse of its process in the form of frivolous or vexatious litigation. The respondent may simultaneously apply for the existing proceedings to be stayed pending the outcome of his or her High Court application in terms of the Vexatious Proceedings Act.

\section{THE WAY FORWARD: OPTIONS FOR REFORM}

Although it can be strongly argued that the Act is innovative legislation that tackles the problem of harassment, it still needs to align with the demands of an ever-changing technological world. ${ }^{103}$ In particular, there is a need to deal with the contradictions that emanate from the defragmented cyber-legislation

\footnotetext{
$S 2(1)(c)$ of the Vexatious Proceedings Act.

Absa Bank Ltd v Dlamini 2008 (2) SA 262 par 32.

Cohen $v$ Cohen 2003 (1) SA 103.

14 AC 665.

103 Bandel "Legislating Against Cyber Crime in Southern African Development Community: Balancing International Standards with Country-Specific Specificities" 201812 International Journal of Cyber Criminology 10.
} 
framework applicable to harassment. 104 The Act must be harmonised with other cyber-related legislation in an attempt to minimise the risk of double regulation and obfuscation. ${ }^{105}$

Further, the Act must take into account and include new and innovative methods of harassment in cyberspace - such as the use of automatic nonhuman agents or third-party action through the use of computer software, impersonation and instigation of third parties. ${ }^{106}$ To further achieve regulatory equilibrium in the protection of rights, a gradation model for remedies and punishment should be adopted. The test of rationality, which is based on the subjective facts and circumstances of each case, should be cautiously applied in order adequately to balance a number of individual rights. Additionally, public policy exceptions should be made in respect of legitimate functions such as police investigations and debt collection not amounting to harassment or intimidation. ${ }^{107}$

\section{CONCLUSION}

This article has demonstrated that the Act has been enacted to give effect to the protection of individual fundamental rights, including but not limited to, the right to equality, privacy, dignity and freedom and security of the person. ${ }^{108}$ In order for the Act to achieve this purpose, it aims to afford victims of harassment an effective remedy against such behaviour. ${ }^{109}$ The Act is therefore necessary in a constitutional democracy. However, the Act should have been drafted to provide maximum protection to deserving victims of human rights violations while still minimising the potential for abuse by unscrupulous litigants by way of an interpretation of the Act that creates unjust legal remedies. This article has further shown that although the Act sought to provide maximum protection to victims, it was not drafted to minimise the potential for abuse by unscrupulous litigants.

This article has explored the definition of harassment ${ }^{110}$ as provided for in the Act, taking into account the purpose of the Act. ${ }^{111}$ The definition of harassment is couched widely in a manner that contributes to the

104 Clough Principles of Cybercrimes (2015) 4.

105 Lohse "The Meaning of Harmonisation in the Context of European Union Law: a Process in Need of Definition" in Andernas and Andersen (eds) Theory and Practice of Harmonisation (2011) 282.

106 Vasilescu "Illegal Interception of Computer Data Transmission in the Regulation of the New Romanian Criminal Code" 201516 Journal of Law and Administrative Sciences 230.

107 Deepa and Ghatak "Mitigating Cyber Sexual Harassment: An Insight from India" 20181 Asian Themes in Social Sciences Research 40.

108 S 9(1) (equality) and s 10 (human dignity) of the Constitution, 1996.

109 Preamble to the Act.

$110 \mathrm{~S} 1(1)$ of the Act.

111 The Preamble to the Act provides the purpose of Act 17 of 2011 as follows: "Since the Bill of Rights in the Constitution of the Republic of South Africa, 1996, enshrines the rights of all people in the Republic of South Africa, including the right to equality, the right to privacy, the right to dignity, the right to freedom and security of the person, which incorporates the right to be free from all forms of violence from either public or private sources, and the rights of children to have their best interests considered to be of paramount importance; and in orde to (a) afford victims of harassment an effective remedy against such behaviour; and (b) introduce measures which seek to enable the relevant organs of state to give full effect to the provisions of this Act." 
achievement of the purpose of the Act, but simultaneously, as a consequence of the wideness of the definition, the Act finds itself vulnerable to abuse. This situation occurs when the complainant's rights to equality or human dignity ${ }^{112}$ are favoured over the rights of the respondent - that is, their rights to privacy or freedom of expression.

The Act provides for a speedy and effective remedy for those who have legitimately experienced harassment, which qualities likewise open the Act to abuse: first, unlike under the DVA, a complainant is not required to prove any type of relationship to the respondent, let alone a domestic relationship, which criterion was often a deterring factor for unscrupulous litigants. Secondly, the complainant is not required to prove a pattern of behaviour or even repetitive behaviour by a respondent; owing to the wide definition of harassment, ${ }^{113}$ a single act of harassment may be enough and easy to conjure. Thirdly, the complainant may be a minor without the assistance of his or her parent or guardian, thereby increasing the litigation between school children who are now encouraged to take their schoolyard disputes to court. Fourthly, Internet or cyber-bullying is included in the definition of harassment and the Act allows for the disclosure of information pertaining to an alleged respondent, thereby encouraging an unscrupulous litigant to conjure cyber-bullying evidence in order to obtain details pertaining to the respondent from the service provider as provided for in the Act and thereby infringing the respondent's right to privacy. ${ }^{114}$

While a complainant can easily obtain a remedy, those respondents who have not engaged in harassing behaviour may conversely find themselves at the mercy of an automatic warrant of arrest obtained by an unscrupulous and vengeful complainant, sometimes even without application of the audi alteram partem principle. The magistrates' court does not have inherent jurisdiction to prevent frivolous or vexatious proceedings against a respondent. The Act has done little to protect a respondent from a vexatious complainant and has only provided two remedies - namely, proving that a false statement has been made by the complainant, and secondly requesting a costs order against the complainant. ${ }^{115}$ Both remedies appear to offer little solace to a respondent who is at the mercy of an unyielding litigant. In these instances, the respondent may be well advised to incur the costs associated with a High Court application and use the Vexatious Proceedings Act to approach the High Court for an appropriate order. Therefore, although the Act is necessary, it has not sought to protect all parties involved and has left a lacuna that can be exploited by vengeful and unscrupulous litigants.

\footnotetext{
S 9 and 10 of the Constitution of the Republic of South Africa, 1996.

13 S 1(1) of the Act.

114 Salter and Bryden "I Can See You: Harassment and Stalking on the Internet" 200918 Information and Communications Technology Law 102; Sissing and Prinsloo "Contextualising the Phenomenon of Cyber Stalking and Protection from Harassment in South Africa" 201315 Acta Criminologica: African Journal of Criminology and Victimology 15.

115 See heading 7 above.
} 